\title{
Dose-dependent effect of plants of the Lamiaceae family on the concentration of methane, fatty acids and nitrogen in the ecosystem in vitro
}

\author{
Vitaliy Ryazanov, Galimzhan Duskaev, and Konstantin Denisenko \\ Federal Research Centre of Biological Systems and Agrotechnologies, RAS, Orenburg, Russia
}

\begin{abstract}
Fermentation processes in the rumen of ruminants determine how much final metabolites and their derivatives will be formed, which are necessary for the full development of the organism, the level of productivity, and also affect the level of formation of endogenous substances, namely, greenhouse gas emissions. These criteria lead us to the search for new feed products that improve the metabolic processes of the rumen and the digestive system as a whole, so phyto-substances can serve as an alternative. The article presents the results of in vitro study of the influence of Salviae folia, Scutellaria baicalensis, Oríganum vulgáre on formation of methane, synthesis of volatile fatty acids and nitrogen, as the main indicator parameters of the enzymatic activity of the rumen of ruminants. It was found that when using phyto- substances: Salviae folia and Scutellaria baicalensis, more acetic and propionic acid was formed, Oríganum vulgare in various dosages shifted towards propionic and valeric acid. Formation of a larger amount of microbial protein $(\mathrm{P} \leq 0.05)$ with use of Salviae folia, Scutellaria baicalensis, Oríganum vulgáre in various dosages was established. Methane production decreased with use of Oríganum vulgáre.
\end{abstract}

\section{Introduction}

Fermentation processes in the rumen of ruminants determines how much final metabolites and their derivatives will be formed, which are necessary for full development of the body, the level of productivity, and also affect the level of formation of endogenous substances, namely, greenhouse gas emissions.

Use of phyto-substances in ruminant feeding can regulate enzymatic processes in the rumen $[1,2]$. Wherein, use of phytobiotics can serve as the basis for alternatives to use of antibiotics in animal husbandry [3]. It is known that feeding of phytobiotics or preparations based on them to cattle promotes better feed conversion, improves nitrogen metabolism, namely, formation of microbial protein, synthesis of volatile fatty acids and the general state of the animal's body [4]. Currently, impact of plant extracts and phyto-substances on formation of methane in the rumen is being assessed [5], a positive effect is noted from their use in terms of reducing the concentration.

A wide range of properties of phyto-substances opens up a wide range of possibilities for studying their effect on metabolism in the rumen of ruminants. From the above, it follows 
that the issue of use of phyto-substances in feeding cattle remains open and requires further study.

\section{Materials and Methods}

\subsection{Object of the Study}

Ruminal fluid, phyto-substances

\subsection{Experiment Scheme}

The study of the influence of phyto-substances was carried out on a model of Kazakh whiteheaded bulls with chronic rumen fistula $(n=3)$, (at the age of 9-10 months, with an average weight of $225-230 \mathrm{~kg}$, diet: hay $-70 \%$; grain feed $-30 \%$, free access to the water). The studies were carried out by the Latin square method. Keeping the animals and procedures within the experiments were in accordance with the instructions and recommendations of the Russian regulations (Order of the Ministry of Health of the USSR No. 755 dated August 12, 1977) and The Guide for Care and Use of Laboratory Animals (National Academy Press, Washington, D.C., 1996). Every effort has been made to minimize animal suffering and to reduce the number of samples used. The studies were carried out by the in vitro method using the device - ANKOM Daisy II incubator (modifications D200 and D200I) according to the specialized method. Each experiment was carried out in triplicate. After incubation, air samples were taken to determine the level of methane on Kristallux-2000M device by gas chromatography. Laboratory studies were carried out at the Testing Center of the Center for Collective Use of the Federal Research Center of the BST of the RAS: the level of volatile fatty acids (VFA) in the contents of the rumen was determined by gas chromatography using gas chromatograph Crystallux-4000M, determination of nitrogen forms - according to GOST 26180-84. The study used phyto-substances of the Lamiaceae family: Salviae folia, Scutellaria baicalensis, Oríganum vulgáre.

\section{Study Results}

When assessing the efficiency of using phyto-substances it is possible to judge by the amount of volatile fatty acids formed in the rumen, which are directly a direct source of energy for the body.

Therefore, when using Salviae folia, the highest concentration values for volatile fatty acids were $1.6 \mathrm{~g} / \mathrm{kg} \mathrm{DM}$ for the dosage: acetic $(7.3 \pm 0.004 \mathrm{mmol} / 100 \mathrm{ml})(\mathrm{P} \leq 0.01)$; propionic $(4.6 \pm 0.007 \mathrm{mmol} / 100 \mathrm{ml})(\mathrm{P} \leq 0.01)$; butyric $(5.8 \pm 0.002 \mathrm{mmol} / 100 \mathrm{ml})(\mathrm{P} \leq 0.05)$; valeric $(4.1 \pm 0.004 \mathrm{mmol} / 100 \mathrm{ml})(\mathrm{P} \leq 0.01)$; caproic $(1.4 \pm 0.002 \mathrm{mmol} / 100 \mathrm{ml})(\mathrm{P} \leq 0.05)$ acid.

The concentration of volatile fatty acids using Scutellaria baicalensis was lower for all dosages, except for caproic acid, its content was significantly different from the others and was $61.5 \%$ higher than that of Salviae folia and $42.3 \%$ of Oríganum vulgáre. Further study of phyto-substances, namely, Oríganum vulgáre at a dosage of $0.2 \mathrm{~g} / \mathrm{kg} \mathrm{DM}$, was noted by increase in concentration for propionic, butyric and valeric acids. The content of propionic acid was higher by $7.7 \%$, butyric acid - by $2.7 \%$, and valeric acid - by $42.5 \%$ in comparison with Salviae folia. The volume of acetic acid was at the same level as for Scutellaria baicalensis and amounted to $(1.6 \pm 0.003)(\mathrm{P} \leq 0.05) \mathrm{mmol} / 100 \mathrm{ml}$ (Fig. 1). 


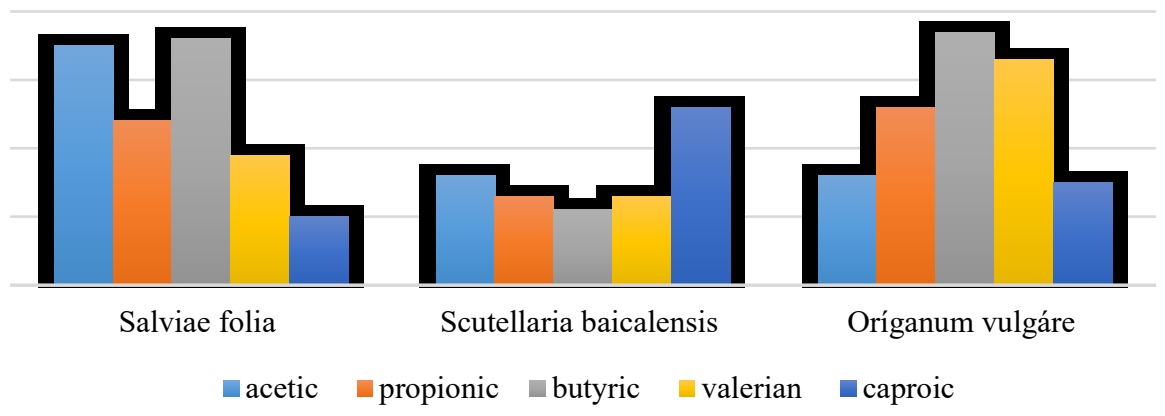

Fig. 1. Concentration of isolated volatile fatty acids in rumen fluid when using phyto-substances, $\mathrm{mmol} / 100 \mathrm{ml}$

Supply of the body with amino acids and the synthesis of microbial protein determines the intake and formation of nitrogenous substances in the rumen. Studying the effect of phyto-substances in our experiment, the highest value for the content of total and protein nitrogen was found for a dosage of $0.8 \mathrm{~g} / \mathrm{kg}$ DM Salviae folia, $0.15 \mathrm{~g} / \mathrm{kg}$ DM Scutellaria baicalensis, and $0.3 \mathrm{~g} / \mathrm{kg}$ DM Oríganum vulgáre. An insignificant decrease in the ammoniacal form of nitrogen was revealed for dosages of 1.6 and $2.4 \mathrm{~g} / \mathrm{kg} \mathrm{DM}$ of Salviae folia, in contrast to the dosage of $0.8 \mathrm{~g} / \mathrm{kg} \mathrm{DM}$, the difference was $5.5 \%$. For a dosage of 0.2 and $0.3 \mathrm{~g} / \mathrm{kg}$ DM Oríganum vulgáre, the content of urea nitrogen was $5.3 \%$ and $10.0 \%$ higher, respectively, than for a dosage of $0.6 \mathrm{~g} / \mathrm{kg}$ DM (Table 1).

Table 1. Nitrogen content in rumen fluid in vitro at various dosages of phyto-substances, $\mathrm{mg} / \%$

\begin{tabular}{|c|c|c|c|c|c|c|}
\hline Name & \multirow{2}{*}{$\begin{array}{c}\text { Dose, } \\
\mathrm{g} / \mathrm{kg} \mathrm{DM}\end{array}$} & \multicolumn{5}{|c|}{ Forms of nitrogen, mg/\% } \\
\cline { 3 - 7 } & & Total & $\begin{array}{c}\text { Non- } \\
\text { protein }\end{array}$ & Ammonia & Urea & Protein \\
\hline \multirow{3}{*}{ Salviae folia } & 0.8 & $86.1 \pm 1.4^{*}$ & $28.7 \pm 2.1$ & $6.3 \pm 1.3^{*}$ & $6.38 \pm 1.0$ & $57.4 \pm 0.9^{*}$ \\
\cline { 2 - 7 } & 1.6 & $72.1 \pm 1.8$ & $37.1 \pm 1.3$ & $5.95 \pm 0.5$ & $6.0 \pm 0.8$ & $35.0 \pm 1.2$ \\
\cline { 2 - 7 } & 2.4 & $80.5 \pm 1.7^{*}$ & $31.5 \pm 1.4$ & $5.95 \pm 1.1$ & $4.88 \pm 1.6$ & $49.0 \pm 1.1^{*}$ \\
\hline Scutellaria baicalensis & 0.15 & $85.9 \pm 1.5^{*}$ & $36.6 \pm 1.2$ & $6.1 \pm 1.4$ & $6.2 \pm 1.4$ & $49.3 \pm 1.7^{*}$ \\
\cline { 2 - 7 } & 0.2 & $83.0 \pm 1.6$ & $36.2 \pm 2.5$ & $5.9 \pm 1.0$ & $4.7 \pm 1.3$ & $46.8 \pm 1.4^{*}$ \\
\cline { 2 - 7 } & 0.3 & $84.3 \pm 1.5^{*}$ & $39.6 \pm 2.3^{*}$ & $6.23 \pm 1.2$ & $5.8 \pm 1.6$ & $44.7 \pm 1.3$ \\
\hline Oríganum vulgáre & 0.2 & $53.2 \pm 2.3$ & $26.2 \pm 1.9$ & $5.6 \pm 1.6$ & $7.13 \pm 0.9$ & $26.95 \pm 1.1$ \\
\cline { 2 - 7 } & 0.3 & $89.6 \pm 1.4^{*}$ & $36.4 \pm 1.1$ & $5.95 \pm 1.5$ & $7.5 \pm 1.7$ & $53.2 \pm 0.7^{*}$ \\
\cline { 2 - 7 } & 0.6 & $74.2 \pm 1.9^{*}$ & $23.1 \pm 0.9$ & $6.65 \pm 1.8^{*}$ & $6.75 \pm 1.2$ & $51.1 \pm 0.5^{*}$ \\
\hline
\end{tabular}

Note:* - P $\leq 0.05 ; \mathrm{DM}$ - dry matter

Use of phyto-substances in feeding the cattle can influence the processes of methanogenesis and contribute to lower energy losses in animals with its conversion into the body's products, reducing the effect of greenhouse gas emissions. An in vitro study of phytosubstances of the Lamiaceae family made it possible to obtain the following data on formation of methane, the highest concentration value was noted for a dosage of $1.6 \mathrm{~g} / \mathrm{kg}$ DM of Salviae folia; it was higher than for a dosage of 0.8 and $2.4 \mathrm{~g} / \mathrm{kg} \mathrm{DM}$ in the same group by $20.5 \%$ and $29.7 \%$, respectively.

It is worth noting that in the Salviae folia group, the average methane concentration was higher than in the Scutellaria baicalensis and Origanum vulgáre groups. With introduction of Scutellaria baicalensis at a dosage of $0.3 \mathrm{~g} / \mathrm{kg}$ DM, the lowest methane concentration was noted in Oríganum vulgáre as well as at a dosage of $0.6 \mathrm{~g} / \mathrm{kg} \mathrm{DM}$, the difference was $23.1 \%$. Wherein, the average value of methane concentration in the Origanum vulgáre group in 
comparison with Salviae folia and Scutellaria baicalensis was lower by $32.4 \%$ and $26.5 \%$, respectively (Table 2).

Table 2. Methane concentration using phyto-substances in vitro, $\mathrm{g} / \mathrm{m}^{3}, \mathrm{CO}_{2} e / \mathrm{g}$

\begin{tabular}{|c|c|c|c|}
\hline \multirow{2}{*}{$\begin{array}{c}\text { Name } \\
\text { Lamiaceae family }\end{array}$} & \multirow[t]{2}{*}{ Dose, g/kg DM } & \multicolumn{2}{|c|}{ Concentration of methane $\mathrm{CH}_{4}$ in vitro } \\
\hline & & $\mathrm{CH}_{4}, \mathrm{~g} / \mathrm{m}^{3}$ & Equivalent of $\mathrm{CO}_{2} e / \mathrm{g}$ \\
\hline \multirow{3}{*}{ Salviae folia } & 0.8 & $11.2 \pm 2.6^{*}$ & $280 \pm 1.2^{*}$ \\
\hline & 1.6 & $14.1 \pm 3.2^{*}$ & $352.5 \pm 2.3$ \\
\hline & 2.4 & $9.9 \pm 2.3$ & $247.5 \pm 1.9$ \\
\hline \multirow[t]{3}{*}{ Scutellaria baicalensis } & 0.15 & $10.4 \pm 2.4$ & $260 \pm 3.4$ \\
\hline & 0.2 & $10.1 \pm 2.3^{*}$ & $252.5 \pm 1.6^{*}$ \\
\hline & 0.3 & $5.3 \pm 1.2^{*}$ & $132.5 \pm 1.7^{*}$ \\
\hline \multirow[t]{3}{*}{ Origanum vulgáre } & 0.2 & $8.5 \pm 1.3^{* *}$ & $213.8 \pm 2.4$ \\
\hline & 0.3 & $8.4 \pm 3.1^{*}$ & $210.8 \pm 1.1$ \\
\hline & 0.6 & $6.9 \pm 2.4^{*}$ & $174.8 \pm 1.8^{*}$ \\
\hline
\end{tabular}

\section{Discussion of Results}

Increasing the volume of production of raising and fattening the cattle is associated with many factors leading to development of a number of diseases (acidosis of the salivary glands, liver abscess, and etc.) and, as a consequence, a decrease in animal productivity [6]. In this regard, the search for new substances that can reduce the load on the digestive tract of animals without disrupting the enzymatic processes in the rumen and without losing productivity is relevant.

In our in vitro study using phyto-substances, the main volatile fatty acids formed during fermentation of feed in the rumen (acetic, propionic, butyric, valeric, caproic acids) were determined. It was found that when using phyto-substances: Salviae folia and Scutellaria baicalensis, more acetic and propionic acid was formed, introduction of Oríganum vulgáre in various dosages led to a shift towards propionic and valeric acid. Similar results were noted in studies $[7,8]$ when using various phyto-substances.

The ability of plant substances to shift the ratio of acetate to butyrate is described in [9], similar results are confirmed in a study [10], which indicates the ability of phytonutrients and phytobiotics to shift fermentation towards formation of propionate and butyrate with inhibition of methanogenesis. In our case, the methane concentration for the Origanum vulgáre sample was lower than for Salviae folia and Scutellaria baicalensis. Studying the phyto-substances according to their ability to form methanogenesis, the authors of [11] found that in different dosages they are able to reduce the amount of methane produced and can be used in feeding. In contrast to our earlier study [12], no decrease in rumen methane production was observed for Oríganum vulgáre. Assessment of the impact of Salviae folia, Scutellaria baicalensis, Oríganum vulgare on the metabolism of various forms of nitrogen in the rumen fluid, namely, formation of a protein form, indicates normal microbiological processes. In study [13], the authors established similar results; it is shown that absorption of non-ammonium nitrogen in the gastrointestinal tract of animals increased when using a diet with addition of plant substances.

Therefore, use of the biomass of plants from the Lamiaceae family: Salviae folia and Scutellaria baicalensis contributes to formation of acetic and propionic acids, Origanum vulgáre - propionic and valeric acids under in vitro ecosystem conditions, an increase in the synthesis of protein fractions, against the background of a decrease in methane values (Oríganum vulgáre). 


\section{Acknowledgements}

This study was performed with the financial support from the Russian Science Foundation (Project No.21-76-10014).

\section{Conflict of Interest}

Authors declares that they have no conflict of interest.

\section{References}

1. I. Karimov, K. Kondrashova, G. Duskaev, O. Kvan, E3S Web of Conferences, 143, 02034 (2020)

2. K. S. Kondrashova, D. B. Kosyan, K. N. Atlanderova, Animal Husbandry and Fodder Production, 103(4), 128 (2020)

3. K. S. Inchagova, G. K. Duskaev, D. G. Deryabin, Microbiology, 88(1), 63 (2019)

4. P. Kuralkar, S. V. Kuralkar, J Ethnopharmacol, 278, 114246 (2021)

5. T. C. de Jesus Pereira, M. L. Pereira, J. V. Moreira, J. A. Azevêdo, R. Batista, V. F. de Paula, B. S. Oliveira, E. de Jesus Dos Santos, Environ Sci Pollut Res Int, 24(5), 4301 (2017)

6. K. M. Benedict, S. P. Gow, T. A. McAllister, C. W. Booker, S. J. Hannon, S. L. Checkley, N. R. Noyes, P. S. Morley, PLoS One., 10(12), e0143995 (2015)

7. G. J. Kolling, S. C. B. Stivanin, A. M. Gabbi, F. S. Machado, A. L. Ferreira, M. M. Campos, T. R. Tomich, C. S. Cunha, S. W. Dill, L. G. R. Pereira, V. Fischer, J Dairy Sci., 101(5), 4221 (2018)

8. P. Løvendahl, G. F. Difford, B. Li, M. G. G. Chagunda, P. Huhtanen, M. H. Lidauer, J. Lassen, P. Lund, Animal, 12(s2), s336 (2018)

9. F. Hashemzadeh-Cigari, M. Khorvash, G. R. Ghorbani, M. Kadivar, A. Riasi, Q. Zebeli, J. Dairy Sci., 97(12), 7487 (2014)

10. J. Oh, E. H. Wall, D. M. Bravo, A. N. Hristov, J Dairy Sci., 100(7), 5974 (2017)

11. A. M. Akanmu, A. Hassen, F. A. Adejoro, Antibiotics (Basel), 9(9), 601 (2020)

12. D. W. Olijhoek, A. L. F. Hellwing, K. Grevsen, L. S. Haveman, M. R. Chowdhury, P. Løvendahl, M. R. Weisbjerg, S. J. Noel, O. Højberg, L. Wiking, P. Lund, J Dairy Sci., 102(11), 9902 (2019)

13. J. A. Aguilar-Hernández, J. D. Urías-Estrada, M. A. López-Soto, A. Barreras, A. Plascencia, M. Montaño, V. M. González-Vizcarra, A. Estrada-Angulo, B. I. CastroPérez, R. Barajas, H. I. Rogge, R. A. Zinn, J. Anim Sci. 94(1), 267 (2016) 